\title{
Improving the physics problem solving and problem posing skills of prospective physics teachers
}

\author{
Sema Çıldır* \\ Faculty of Education, Department of Mathematics and Science Education, Hacettepe University, \\ Ankara, Turkey
}

\begin{abstract}
This study was conducted with the aim of providing awareness and skill to the prospective physics teachers in the areas problem posing and problem solving. In this study, which was carried out according to qualitative research methods, information was given about problem building and solving approaches, and then the process of transforming this knowledge into skills was examined. To this end, the prospective teachers were asked to solve at least two physics problems according to the Polya's problem solving steps and explain each step they applied in detail. In the same manner, they were asked to pose at least two physics problems and solve their own problems according to the Polya's problem solving steps in the problem posing stage. The process was continued through semistructured interviews and the opinions and suggestions of the prospective teachers were obtained at the end of the study. As a result of the study, it was determined that prospective teachers had difficulty in problem posing and they preferred to pose free problems, in the problem solving, they did not use techniques such as drawing, graphing etc. in the identification step of a problem, some prospective teachers could not perform the evaluation stage and these results were discussed with the prospective teachers. It was concluded that the prospective teachers wanted to use their problem posing and solving skills in their professional lives in order to reinforce the subject and to increase the motivation. In order to improve the creative problem solving and critical thinking skills of the prospective teachers, it is suggested that problem posing and solving skills should be included more in the curriculum.
\end{abstract}

\section{Introduction}

Every day in our lives we encounter some minor problems. We maintain our lives by solving many of these problems at that moment. However, some of the problems we face are very complex and over time, these problems start to bother us and affect our mood. Eventually, these problems become vexing problems and must be solved as soon as

\footnotetext{
* Corresponding author: sselman@hacettepe.edu.tr
} 
possible. Regardless of the source and the difficulty level, problem solving requires a skill. It is important to identify and understand the problem in a short time and to develop strategies for solutions.

Problem solving and creative problem solving skills, which are one of the 21 st century skills, are now the skills that all individuals should possess[1]. The mission of providing these skills to the students in the school belongs to the teachers. Students who have the ability to consider life from different perspectives gain the ability to handle the problems they face from different angles. These students will try different solutions for the problems they experience both in and out of school. Students will be able to test the accuracy of the solution by using different methods.

Training programs should also be prepared to support teachers and students in this regard. Teachers who are the practitioners of these programs should acquire these skills first. For this reason, providing merely field knowledge or laboratory skills in teacher training schools is not enough. The problem solving skills of prospective teachers should also be supported.

There are strategies suggested to be used for problem solving. The problem solving approaches and strategies suggested by the leading scientists in this field are as follows [2]:

$\checkmark$ John Dewey's Reflective Thinking Approach and Problem Solving Strategy

$\checkmark$ Alex Osborn's Problem Solving Approach and Strategy

$\checkmark$ Bingham's Problem Solving Approach and Strategy

$\checkmark \quad$ Polya's Problem Solving Approach and Strategy

$\checkmark \quad$ Thorndike's Problem Solving Approach and Strategy

$\checkmark \quad$ Köhler's Problem Solving Approach and Strategy

$\checkmark$ Herman's Problem Solving Approach and Strategy

$\checkmark$ Problem Solving Steps according to Gallagher and Stepien

$\checkmark \quad 5$-Step Problem Solving Strategy by Heller et al. Beincher's GOAL Problem Solving Strategy

In this study, Polya's problem solving approach and strategies will be used. Both routine and non-routine types of problems are frequently used in education. Polya's approach will be preferred in solving these kinds of problems. The four-step problemsolving process proposed by Polya is the most commonly used strategy for solving routine and non-routine problems in general.

In his book "How to Solve it", George Polya stated that the knowledge acquired during the problem-solving process should be combined with new and unordinary ways [3]. He addressed the problem solving process in four steps:

1. Understand the problem

2. Devise a plan for the solution

3. Carry out the plan

4. Look back/evaluate the results

One another method to improve the problem solving skills is to increase the problem posing skills [4]. Likewise, Palmin and Illies, in their study conducted on 2004, emphasized that it is necessary to pose problems as a first step of being a creative problem solver. Problem solving, -as it is in problem solving- requires prior knowledge on the relevant issue[5]. There are many studies conducted on the importance of problem posing and its relationship with problem solving [6,7]. Problem posing can be done in different ways. We can classify these methods in three groups, which are free problem posing, semi-structured and structured problem posing [8].

1. Free Problem Posing: There are no restrictions for the problem to be posed [9]. The person who set up the problem is expected to act creatively.

2. Semi-Structured Problem Posing: Students use their old mathematical knowledge, experience, and skills to complete or structure a given case. 
a) Mathematical Case: Concepts and components are provided, but the actual question is not given.

b) Open-ended Problem Posing: An incomplete scenario is provided. Students are asked to complete this scenario by brainstorming.

c) Real life issues are simulated and concretized.

3. Structured Problem Posing: It is asked to rewrite a previously known and solved problem. The questions can be rewritten by changing the given contents or changing only the chosen ones.

\subsection{The purpose of the study}

According to PISA 2015 report, Turkey is far behind in the rank of problem solving skills when compared to science-maths-reading skills[10]. This situation should be addressed mindfully and the reasons for this need to be investigated. Providing students the important skills of this century such as problem solving and creative problem solving in school life is quite important. Teachers play a great role in providing students with the knowledge and skills they need. For this reason, teachers should use not only problem solving skills but also problem posing skills. Thus, teachers can improve their students' creative problemsolving skills with the problems they have posed [11, 12].

When all these are considered, it is important that prospective teachers gain both the ability to apply problem solving strategies effectively and problem posing skills while studying at university. The aim of this study is to inform prospective physics teachers about problem solving and posing strategies and to examine the process of prospective teachers to transform this knowledge into skills. In the study, it is essential to determine the number of solution steps and the way they are applied when solving the problems, not the success of prospective teachers in solving the problems. For this reason, no scoring was made for prospective teachers. The research questions of the study are as follows:

1) How do prospective physics teachers use the strategies in solving physics problems and evaluate their own solutions?

2) Which problem solving approaches do prospective physics teachers use to pose their unique problems?

\section{Method}

This study was conducted in accordance with the qualitative research methods. Separate worksheets were prepared by prospective teachers for problem solving and posing procedures. The evaluation of the process was supported by semi-structured interviews.

\subsection{Study Group}

The study was carried out at a state university in Turkey. Seven prospective physics teachers studying in the Faculty of Education, Department of Physics Education as senior students participated in the study. This study is limited in terms of the number of participants as the senior students are few in number and the participants are determined on a voluntary basis.

\subsection{Data Collection Tools and Analysis}

The research continued throughout the semester. Firstly, prospective teachers were provided theoretical information about problem, problem types and problem solving steps 
and content was supported with sample applications. At the end of this stage, prospective teachers were expected to solve at least 2 problems. They were asked to solve and examine these problems step by step according to the Polya's problem solving steps.

The research maintained with the theoretical knowledge and practices provided to improve problem posing skills. At the end of this stage, prospective teachers were asked to pose at least 2 problems on the subject they wanted.

In the last stage, semi-structured interviews were conducted with the students and the data obtained in the first two stages were detailed. It was aimed to increase the validity of the research through this.

\section{Findings}

Problem Solving Stage:

According to the findings obtained from the worksheets, the subject of the problems selected by the prospective teachers for the solution are as follows:

Table 1. Distributions of preferred subjects in problem solving.

\begin{tabular}{|c|c|c|}
\hline Course & Subject & $\begin{array}{c}\text { Number of } \\
\text { Questions }\end{array}$ \\
\hline Mechanics & Simple Machines & 5 \\
\cline { 2 - 3 } & Rectilinear Motion & 1 \\
\hline $\begin{array}{c}\text { Matter and Properties } \\
\text { of Matter }\end{array}$ & Density, Specific Heat, Pressure & 5 \\
\hline Electric & Types of Electrification & 2 \\
\hline Atomic Physics & Scattering & 1 \\
\hline
\end{tabular}

It was determined in the interviews that prospective teachers found themselves more competent about Mechanics (Simple Machines) and Properties of Matter. It is a noteworthy finding that the topic of Simple Machines is a preferred subject even though it is not included in the course of Mechanics in the curriculum.

According to the findings, all the students preferred to underline the words they found important in the questions during the stage of understanding the problem. Semi-structured interviews revealed that they preferred this because they found it more practical.

They did not use graphics and figures to restate the problem. The reason for this was explained by the participants as the problem is not suitable for this, they do not think that this is required, the problem has already been given in the figure as explained.

None of the students provided a list of data or requests. They explained the reason for that with the fact that the question includes figure or they do not ask too many answers in questions.

During the planning and application stages, they determined their methods according to the problem type and wrote the necessary explanations as notes.

At the stage of evaluating the results, a student could not exhibit the necessary behavior and this situation was eliminated during the semi-structured interview.

Problem Posing Stage:

After giving the necessary information about problem posing and examining various examples, students were asked to pose their own problems. At this stage, prospective teachers preferred to establish free problems. Students are not constrained in posing free 
problems [8]. In this study, no restriction was imposed. The prospective teachers used their preferences in this direction. The problems were analyzed, and the following findings were obtained.

Table 2. Distributions of preferred subjects in problem posing.

\begin{tabular}{|c|c|c|}
\hline \multirow{2}{*}{ Course } & Subject & $\begin{array}{c}\text { Number of } \\
\text { Questions }\end{array}$ \\
\hline \multirow{3}{*}{ Mechanics } & Momentum Problems & 3 \\
\cline { 2 - 3 } & Circular Motion & 2 \\
\cline { 2 - 3 } Electric & Free Fall & 1 \\
\cline { 2 - 3 } & Coulomb's Law & 1 \\
\cline { 2 - 3 } & Electrical Field & 1 \\
\cline { 2 - 3 } & Resistive Circuits & 1 \\
\hline \multirow{2}{*}{ Waves } & Condenser Circuits & 1 \\
\hline \multirow{2}{*}{ Optics } & Wavelength-Wave Speed & 1 \\
\hline $\begin{array}{c}\text { Matter and Properties } \\
\text { of Matter }\end{array}$ & Mirrors & 1 \\
\cline { 2 - 3 } & Heat and Temperature & 1 \\
\hline
\end{tabular}

The most preferred subject of the prospective teachers when posing problems is the mechanics. However, the simple machines, which are mostly preferred in problem solving, were not preferred in problem posing, instead, the subjects of momentum and circular motion were preferred.

Semi-Structured Interviews:

According to the findings obtained from interviews;

The answers of some prospective teachers to the question of "Did you have any previous knowledge about the problem posing and its methods?" are as follows:

T1. «I had knowledge, but now I can pose problems more easily. »

T2. «I didn't know anything about problem solving before. »

T3. «I didn't have enough information. I'm confident in posing an original problem right now. »

T4. «I've always been interested in problem posing or rather preparing a question book. But I didn't know before that it had details. »

One student gave a negative answer to the question of "Do you think that you have been comprehensively knowledgeable about problem solving skills?". Others stated that at the beginning of the semester there were some steps that they used without realizing, or that they did not know at all, but that they found themselves sufficient after the training.

T1. «I don't have enough information, but after a certain period of practice I can master in this subject. »

Prospective teachers established relationships between problem solving and posing skills and professional competencies in the following categories:

Necessary to be a good teacher (3 people), These skills should be developed (3 people), I found it interesting (1 person).

The answers of some prospective teachers to the question of "Do you think that you can use these skills in your professional life?" are as follows: 
T1 «Yes. I can solve problems in different ways for my students with individual differences. At the same time, I can draw students' attention by motivating them through posing problems with different methods and motivate them for my lesson. "

T2 «In my professional life, I can organize an activity like a problem posing contest by forming groups among students to reinforce the subject with students and enable them to use all the concepts they know about problem posing. »

T3. « In my professional life, I apply the problem solving steps in order for the student to understand the question better. »

\section{Conclusion and discussion}

As a result of the interviews, it was determined that prospective teachers had solved problems randomly without using a strategy or being aware of using a strategy before the study. According to the findings, prospective physics teachers applied their problem solving strategies step by step in the problems they solved. As a result, prospective teachers' awareness on this issue has increased and they gained knowledge and skills. In this sense, this study has attained its aim.

The subjects preferred by prospective teachers frequently are the subjects included in the Mechanics course. This situation can be interpreted as the course in which senior students consider themselves most competent is the mechanics. It has been suggested to take measures to ensure that prospective teachers consider themselves as sufficient in other courses such as electricity, optics etc.

In the step of understanding the problem, it was seen that prospective teachers did not prefer methods such as drawing figures, writing data, and converting the problem into their own sentences. Instead of these methods, they underlined important words. This situation stems from the prospective teachers' willingness to solve the question in a short time. This behavior can be regarded as an old habit because of the fact that they were expected to reach a solution as soon as possible in the university admission exams.

According to the results obtained from the findings, the evaluation step, which is one of the problem solving steps, could not be applied properly and even one of the students had applied it completely wrong. In parallel with these results, Gökkurt et al. (2015) obtained similar results and concluded that students performed poorly in the evaluation step [13]. The evaluation step is an important stage to check the accuracy of the solution. Skipping this step or making an inadequate evaluation eliminates the chance of correcting errors. For this reason, the importance of this step is reemphasized to prospective teachers.

As a result of the interviews, it was found out that prospective teachers had difficulties in posing problems and posed problem types that they had solved frequently before (based on memorization). In fact, the fact that they preferred free problem posing method supports this result. Since there was no limitation, they tended to pose problems according to the certain question types (perhaps even memorized ones). In future studies to be conducted on problem posing, it is recommended that prospective teachers should be particularly directed to semi-structured and structured problem posing methods. Problem posing is effective in the development of problem-solving skills [8]. For this reason, it is recommended that more time should be devoted to problem posing activities in order to eliminate the difficulties experienced by prospective teachers.

According to the semi-structured interviews, it was concluded that prospective teachers considered themselves sufficient in problem solving and posing. The fact that they want to use these skills in their professional lives and that, even better, they want to use them for different purposes is a positive result. For example, the fact that a prospective teacher aims to apply the problem solving steps differently according to the individual differences of her/his students with the aim of providing an environment to the students in which they are 
actively involved and achieving the learning, shows that she/he wants to use problem solving as a teaching method. It is also found out that the same prospective teacher is planning to increase the motivation of the students in the course by posing problems with different methods. The fact that another prospective teacher wants to address the problem posing methods through organizing problem posing competitions in order to enable the students to reinforce the subject or that one another prospective teacher wants to use the solution steps to explain the solution better has brought different dimensions to the use of problem posing and problem solving methods in the lessons. Therefore, it is recommended for researchers to be study in this field to extend the study to a larger sample to include these dimensions.

\section{References}

1. Framework for 21 st Century Learning, P21 Partnership for 21st Century Learning. http://www.battelleforkids.org/learning-hub/learning-hub-item/framework-for-21stcentury-learning

2. E. İnce. Fizik Öğretiminde Problem Çözme, Cevze Kitap, İstanbul, (2017).

3. G. Polya. How to solve it? Doubleday Anchor Books, Doubleday\&Company, Inc.Garden City, New York. Second Editon,(1957).

https://math.hawaii.edu/home/pdf/putnam/PolyaHowToSolveIt.pdf

4. N. Akben. Effects of the Problem-Posing Approach on Students' Problem Solving Skills and Metacognitive Awareness in Science Education, Research in Science Education,1-23 (2018)

5. R.R. Palmon \& J.J. Illies.Leadership and creativity : Understanding leadership from a creative problem-solving perspective, The Leadership Quarterly, 15(1), 55-77, (2004)

6. E. Stoyanova, \& N.F, Ellerton (1996). A framework for research into students' problem posing in school mathematics. In P. Clarkson (Ed.), Technology in mathematics education (pp. 518-525). Melbourne, Australia: Mathematics Education Research Group of Australasia. (1996)

7. M. Tichá \& A. Hošpesová. Problem posing and development of pedagogical content knowledge in preservice teacher training. In V. Durand-Guerrier, S. Soury-Lavergne, \& F. Arzarello (Eds.), Proceedings of the Sixth Congress of the European Society for Research in Mathematics Education (pp. 1941-1950). Lyon, France: Institut National de Recherche Pédagogique. (2009).

8. H. Akay. Problem Kurma Yaklamışı ile Yapılan Matematik Öğretiminin Öğrencilerin Akademik Başarısı, Problem Çözme Becerisi ve Yaratıcılığı Üzerindeki Etkisinin Incelenmesi. Dissertation Thesis, Gazi University, Institute of Educational Sciences, Ankara, (2006)

9. X. Yuan, \& B. Sriraman. An Exploratory Study of Relatonshps Between Students' Creativity And Mathematical Problem-Posing Abilities. The Elements of Creativity and Giftedness in Mathematics. (2010). Retrieved January 31, 2019, from https://hs.umt.edu/math/research/technicalreports/documents/2010/22_YuanSriraman.p df

10. http://www.oecd.org/education/pisa-2015-results-volume-v-9789264285521-en.htm

11. A. Silver Edward \& J. Cai. An analysis of arithmetic problem posing by middle school. Journal for Research in Mathematics Education, 27, 521, (1996) 
12. S. Nixon-Ponder. Teacher to Teacher: Using Problem-Posing Dialogue in Adult Literacy Education. (2001) Retrieved January 31, 2019 from https://www.researchgate.net/publication/234598591

13. B. Gökkurt, T. Örnek, F. Hayat, \& Y. Soylu. Öğrencilerin Problem Çözme ve Problem Kurma Becerilerinin Değerlendirilmesi, Bartın Üniversitesi Eğitim Fakültesi Dergisi, 4(2) 751-77, (2015) 